\title{
A preliminary molecular phylogeny of the genus Scobura, with a synonym of Scobura masutaroi (Lepidoptera, Hesperiidae)
}

\author{
Zhen-Fu Huang ${ }^{1, *}$, Wen Fei ${ }^{1,}$, Min Wang', Hideyuki Chiba², Xiao-Ling Fan' \\ I Department of Entomology, College of Ariculture, South China Agricultural University, Guangzhou 510642, \\ China 2 B. P. Bishop Museum, 1525 Bernice Street, Honolulu, Hawaii, 96817-0916 U.S.A. \\ Corresponding authors: Xiao-Ling Fan (fanxiaol66@scau.edu.cn); Hideyuki Chiba (skipper@i.bekkoame.ne.jp)
}

Academic editor: T. Simonsen | Received 29 July 2016 | Accepted 20 November 2016 | Published 7 December 2016

http://zoobank.org/C230389D-B271-4BB7-94F2-F72516DBC41C

Citation: Huang Z-F, Fei W, Wang M, Chiba H, Fan X-L (2016) A preliminary molecular phylogeny of the genus Scobura, with a synonym of Scobura masutaroi (Lepidoptera, Hesperiidae). ZooKeys 638: 33-44. https://doi. org/10.3897/zookeys.638.10026

\begin{abstract}
A molecular phylogeny of the genus Scobura based on the mitochondrial COI and the nuclear EF-1 $\alpha$ genes using maximum likelihood and Bayesian inference is proposed. The analyses include 19 specimens from nine ingroup species. The monophyly of Scobura is not strongly supported, but two strongly supported monophyletic groups within the genus are recognized: the $S$. coniata group and the $S$. woolletti group. Judging from combination of the molecular evidence and morphological features, the former consists of six species, including S. masutaroi, while four species belong to the latter. S. mouchai Krajcik, 2013 is confirmed to be a syn. n. of $S$. masutaroi Sugiyama, 1996. The key to the species of the genus Scobura is modified to reflect these results.
\end{abstract}

\section{Keywords}

COI, EF-1 $\alpha$, Scobura masutaroi, Scobura mouchai

* These authors contributed equally to this work and should be considered co-first authors.

Copyright Zhen-Fu Huang et al. This is an open access article distributed under the terms of the Creative Commons Attribution License (CC BY 4.0), which permits unrestricted use, distribution, and reproduction in any medium, provided the original author and source are credited. 


\section{Introduction}

The skipper genus Scobura Elwes \& Edwards, 1897 was recently revised by Fan et al. (2010), who recognized 14 species. The genus Scobura, however, includes another species, S. masutaroi, Sugiyama 1996. Fan et al. (2010) overlooked the existence of this taxon and did not include it in their revisional work, which resulted in Krajcik (2013) proposing a new taxon, S. mouchai, from Shaanxi.

Although a comprehensive morphological revision of the genus has been completed, no phylogenetic analysis has been performed to infer relationships within the genus. In the present study, we present a preliminary phylogeny of Scobura, based on molecular evidence. By comparing molecular and morphological evidence, we examine whether $S$. mouchai is a synonym of $S$. masutaroi.

\section{Methods}

\section{Morphological examination}

See Fan et al. (2010) for materials for the morphological study. In order to examine the wing venation, wings were removed from thorax, cleaned with 95\% ethanol, and dyed red with acetocarmine (Wang et al. 2011).

\section{Taxon sampling}

Twenty-three specimens including nine of the 15 valid species of Scobura and four outgroup species were included in the phylogenetic reconstruction. Detailed information on the specimens is provided in Table 1 . Specimens used in this study were mainly deposited in the Insect Collection, Department of Entomology, South China Agriculture University (SCAU), except for some specimens in Kyushu University museum (KU) and Mr. Hiroaki Onodera's private collection.

\section{Laboratory protocols}

Genomic DNA was extracted from the thorax of specimens preserved in ethanol, or from legs of dried specimens, using Magen's Blood/cell/tissue DNA extraction kit. One mitochondrial gene cytochrome coxidase I (COI) and one nuclear gene elongation factor 1- $\alpha$ (EF$1 \alpha$ ) were used as molecular phylogenetic markers. The following primers were used for amplification and sequencing in this study: for COI - primers LCO1490 and HCO2198 (Folmer et al. 1994); for EF- $1 \alpha$ - primers ef 44 and efrcM4 (Monteiro and Pierce 2001). Ploymerase Chain Reaction (PCR) were performed in $20 \mu \mathrm{l}$ volumes containing $1 \mu \mathrm{l}$ 
Table I. Voucher information and GenBank accession numbers for the specimens in this study.

\begin{tabular}{|c|c|c|c|c|c|c|}
\hline Species & Locality & Latitude & Longitude & $\begin{array}{l}\text { Voucher } \\
\text { Number }\end{array}$ & $\mathrm{COI}$ & EF-1 $\alpha$ \\
\hline $\begin{array}{l}\text { Scobura cephaloides } \\
\text { kinkaEvans, } 1949\end{array}$ & China: Hainan & $19.02 \mathrm{~N}$ & $109.53 \mathrm{E}$ & SCAU He102 & KY049936 & KY049958 \\
\hline $\begin{array}{l}\text { Scobura cephaloides } \\
\text { kinkaEvans, } 1949\end{array}$ & $\begin{array}{l}\text { Laos: Luang } \\
\text { Prabang }\end{array}$ & $19.93 \mathrm{~N}$ & $102.07 \mathrm{E}$ & Onodera $\mathrm{He} 553$ & KY049937 & KY049959 \\
\hline $\begin{array}{l}\text { Scobura coniata } \\
\text { Hering, } 1918\end{array}$ & China: Guangdong & $24.91 \mathrm{~N}$ & $113.04 \mathrm{E}$ & SCAU He073 & KY049938 & KY049960 \\
\hline $\begin{array}{l}\text { Scobura coniata } \\
\text { Hering, } 1918\end{array}$ & China: Guangdong & $24.87 \mathrm{~N}$ & $113.03 \mathrm{E}$ & SCAU He472 & KY049939 & KY049961 \\
\hline $\begin{array}{l}\text { Scobura hainana } \\
\text { (Gu \& Wang, 1997) }\end{array}$ & China: Guangdong & $24.87 \mathrm{~N}$ & $113.04 \mathrm{E}$ & SCAU He471 & KY049940 & KY049962 \\
\hline $\begin{array}{l}\text { Scobura hainana } \\
\text { (Gu \& Wang, 1997) }\end{array}$ & China: Guangdong & $24.87 \mathrm{~N}$ & $113.04 \mathrm{E}$ & SCAU He487 & KY049941 & KY049963 \\
\hline $\begin{array}{l}\text { Scobura hainana } \\
\text { (Gu \& Wang, 1997) }\end{array}$ & China: Guangdong & $24.87 \mathrm{~N}$ & $113.04 \mathrm{E}$ & SCAU He488 & KY049942 & KY049964 \\
\hline $\begin{array}{l}\text { Scobura isota } \\
\text { (Swinhoe, 1893) }\end{array}$ & $\begin{array}{c}\text { Thailand: } \\
\text { Kanchanaburi }\end{array}$ & $14.08 \mathrm{~N}$ & $99.36 \mathrm{E}$ & SCAU He538 & KY049943 & KY049965 \\
\hline $\begin{array}{l}\text { Scobura isota (Swinhoe, } \\
1893 \text { ) }\end{array}$ & $\begin{array}{l}\text { Thailand: Mae } \\
\text { Hong Son }\end{array}$ & $19.35 \mathrm{~N}$ & $98.14 \mathrm{E}$ & SCAU He468 & KY049944 & KY049966 \\
\hline Scobura lyso (Evans, 1939) & China: Zhejiang & $30.15 \mathrm{~N}$ & $119.25 \mathrm{E}$ & SCAU He465 & KY049945 & \\
\hline Scobura lyso (Evans, 1939) & China: Zhejiang & $30.15 \mathrm{~N}$ & $119.25 \mathrm{E}$ & SCAU He475 & KY049946 & - \\
\hline $\begin{array}{l}\text { Scobura masutaroi } \\
\text { Sugiyama, } 1996\end{array}$ & China: Sichuan & $29.94 \mathrm{~N}$ & $102.48 \mathrm{E}$ & SCAU He300 & KY049947 & KY049967 \\
\hline $\begin{array}{l}\text { Scobura masutaroi } \\
\text { Sugiyama, } 1996\end{array}$ & China: Sichuan & $29.94 \mathrm{~N}$ & $102.48 \mathrm{E}$ & SCAU He301 & KY049948 & KY049968 \\
\hline $\begin{array}{l}\text { Scobura masutaroi } \\
\text { Sugiyama, } 1996 \\
\text { (=mouchai) }\end{array}$ & China: Shaanxi & $31.91 \mathrm{~N}$ & $106.34 \mathrm{E}$ & SCAU He303 & KY049949 & KY049969 \\
\hline $\begin{array}{l}\text { Scobura parawoolletti } \\
\text { Fan et al., } 2010\end{array}$ & China: Hainan & $19.03 \mathrm{~N}$ & $109.53 \mathrm{E}$ & SCAU He116 & KY049950 & KY049970 \\
\hline $\begin{array}{l}\text { Scobura stellata Fan et al., } \\
2010\end{array}$ & China: Guangdong & $24.92 \mathrm{~N}$ & $113.01 \mathrm{E}$ & SCAU He036 & KY049951 & KY049971 \\
\hline $\begin{array}{l}\text { Scobura woolletti } \\
\text { (Riley, 1923) }\end{array}$ & $\begin{array}{l}\text { Indonesia: } \\
\text { Kabandungan }\end{array}$ & $6.77 \mathrm{~S}$ & $106.60 \mathrm{E}$ & KU He535 & KY049952 & KY049972 \\
\hline $\begin{array}{l}\text { Scobura woolletti (Riley, } \\
1923 \text { ) }\end{array}$ & $\begin{array}{c}\text { Indonesia: } \\
\text { Kabandungan }\end{array}$ & $6.77 \mathrm{~S}$ & $106.60 \mathrm{E}$ & KU He536 & KY049953 & KY049973 \\
\hline $\begin{array}{l}\text { Scobura woolletti } \\
\text { (Riley, 1923) }\end{array}$ & $\begin{array}{c}\text { Indonesia: } \\
\text { Kabandungan }\end{array}$ & $6.77 \mathrm{~S}$ & $106.60 \mathrm{E}$ & KU He537 & KY049954 & KY049974 \\
\hline $\begin{array}{l}\text { Suastus gremius (Fabricius, } \\
1798 \text { ) }\end{array}$ & China: Guangdong & $23.15 \mathrm{~N}$ & $113.34 \mathrm{E}$ & SCAU He157 & KY049955 & KY049975 \\
\hline $\begin{array}{l}\text { Suada swerga (deNicéville, } \\
\text { 1884) }\end{array}$ & $\begin{array}{c}\text { Thailand: Chiang } \\
\text { Mai }\end{array}$ & $18.80 \mathrm{~N}$ & $98.92 \mathrm{E}$ & SCAU He495 & KY049956 & KY049976 \\
\hline $\begin{array}{l}\text { Hyarotis quinquepunctatus } \\
\text { Fan \& Chiba, } 2008\end{array}$ & China: Hainan & $19.03 \mathrm{~N}$ & $109.54 \mathrm{E}$ & SCAU He114 & - & KY049977 \\
\hline $\begin{array}{l}\text { Zographetus satwa } \\
\text { (deNicéville, 1884) }\end{array}$ & China: Guangdong & $24.88 \mathrm{~N}$ & $113.03 \mathrm{E}$ & SCAU He442 & KY049957 & KY049978 \\
\hline
\end{tabular}


template DNA, $2 \mu \mathrm{l} 10 \times$ buffer, $1.6 \mu \mathrm{dNTPs}$ (containing $2.5 \mathrm{mM}$ of each dNTP), $0.8 \mu \mathrm{l}$ of each primer $(10 \mathrm{uM}), 0.2 \mu \mathrm{l}$ Taq Polymerase $(2 \mathrm{U} / \mu \mathrm{l})$, and $13.6 \mu \mathrm{ddH}_{2} \mathrm{O}$. The PCR Products were amplified using initial denaturation at $94^{\circ} \mathrm{C}$ for $4 \mathrm{~min}, 35$ cycles of denaturation at $94^{\circ} \mathrm{C}$ for $30 \mathrm{~s}$, annealing at $47^{\circ} \mathrm{C}(\mathrm{COI})$ for $45 \mathrm{~s}, 55^{\circ} \mathrm{C}(\mathrm{EF}-1 \alpha)$ for $1 \mathrm{~min}$, elongation at $72{ }^{\circ} \mathrm{C}$ for $1.5 \mathrm{~min}$, and final elongation at $72{ }^{\circ} \mathrm{C}$ for $5 \mathrm{~min}$.

Amplified DNA products were purified using an Agarose Gel Extraction kit (Magen Biotech), and directly sequenced, or cloned with pMD18-T vector (Takara Inc), and then sequenced. Sequencing was performed using the ABI 3730 automated sequencer. All sequences were submitted to the Genbank database (accession numbers are given in Table1).

\section{Phylogenetic analyses}

Alignment of the DNA sequences were performed in Clustal X (Thompson et al. 1997) and edited manually in MEGA 6.0 (Tamura et al. 2013). All base frequencies and molecular character statistics were calculated in MEGA 6.0. Phylogenetic trees were constructed under maximum Likelihood (ML) and Bayesian inference (BI) criteria. For ML analysis, RAxML version 8 (Stamatakis et al. 2014) was used on a concatenated data set of two genes, with 1000 rapid bootstrap replicates using GTR+G substitution model on the CIPRES Science Gateway (Miller et al. 2010). BI was carried out using Markov Chain Monte Carlo (MCMC) randomization in MrBayes v3.2.3 (Ronquist et al. 2012). We used reversiblejump MCMC to allow for sampling across the entire substitution rate models. Four Markov chains (three heated chains, one cold) were run for 500, 000 generations, with the first $25 \%$ of sampled trees discarded as burn-in. The two independent runs were considered to have converged when the standard deviation of split frequencies value was $<0.01$. The convergence of the analysis was determined in Tracer v1.6 (Rambaut et al. 2014). Bayesian posterior probabilities $(\mathrm{PP})$ and $\mathrm{ML}$ bootstrap values $(\mathrm{BP})$ were used to evaluate branch support.

\section{Results}

\section{Sequence data}

From a total of 23 samples, 22 sequences for COI and 21 for EF- $1 \alpha$ were obtained. The alignment of the combined sequences consisted of a total of $1724 \mathrm{bp}$ (658 bp of COI and 1066 bp of EF- $1 \alpha$ genes, respectively), including 277 variable and 200 informative sites.

The pairwise $\mathrm{P} 2 \mathrm{~K}$ distances among the sequences were variable between genes. The ranges of sequence divergences for two loci and ingroup taxa are: COI (0-12.4\%), EF$1 \alpha(0-5.0 \%)$. For COI, sequence divergence between conspecific individuals ranged from 0 to $0.6 \%$; inter-specific genetic distances ranged from $3.6 \%$ to $12.4 \%$ with divergences among species averaging 7.9\% (Table 2). 


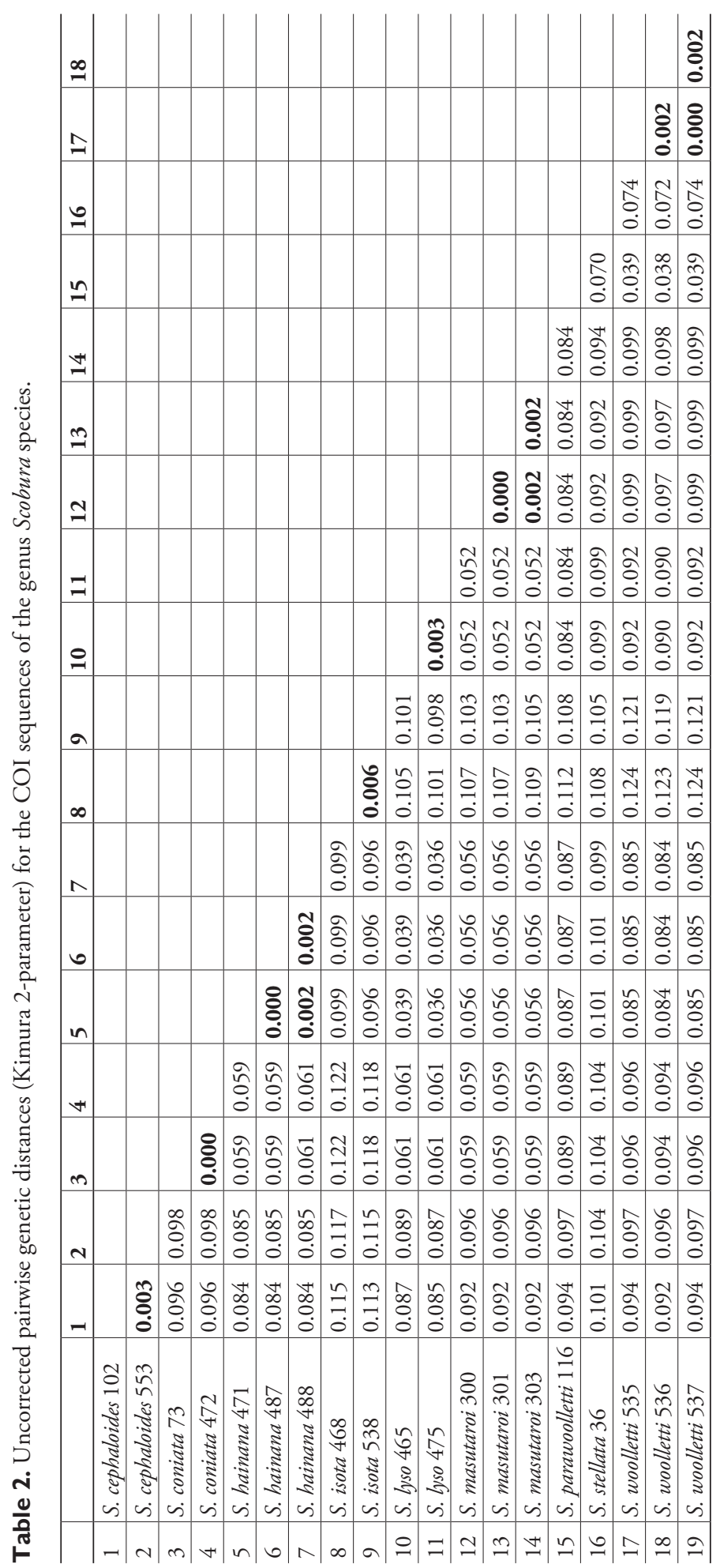




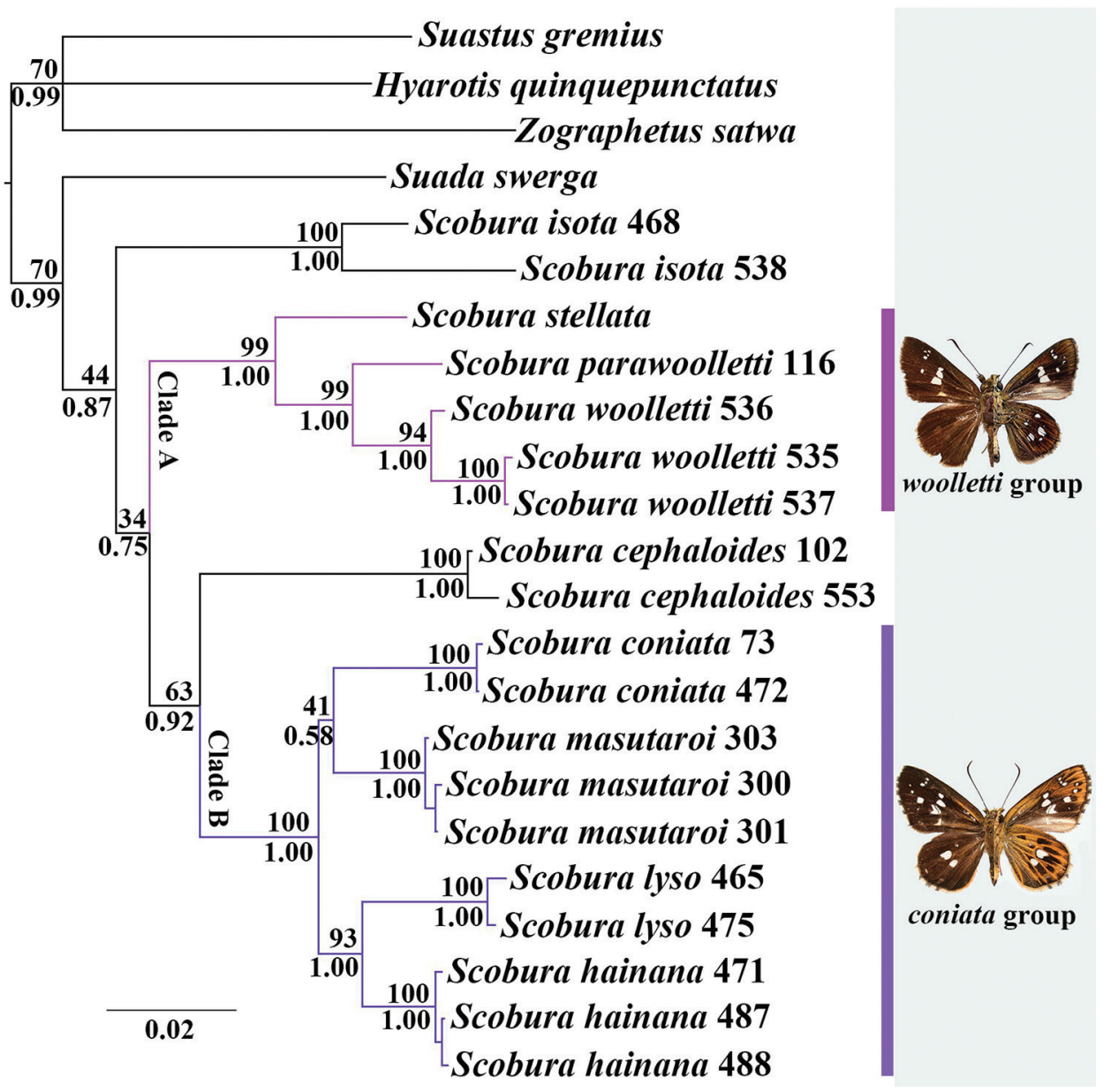

Figure I. Majority-rule consensus tree from the Bayesian analysis (BI) of the concatenated COI and EF-1 $\alpha$ sequences. Values at nodes represent the bootstrap support (BS) values of the maximum likelihood $(\mathrm{ML})$ and the posterior probabilities (PP) of $\mathrm{BI}$ analyses, respectively (BP/PP).

\section{Phylogenetic analyses}

The two model-based analyses (BI and ML) revealed nearly identical topologies, differing mainly in branch support (Fig. 1). In both analyses, the monophyly of the genus Scobura is weakly supported $(\mathrm{BP}=44, \mathrm{PP}=0.87)$. Within the genus, although support for the basal clades was low, the Scobura species included here are clearly distinguished from each other, and formed four clades: the $S$. isota clade (which only included two representative specimens), Clade A, the $S$. cephaloides clade (only with two representative specimens), and Clade B. Clade A is comprised by S. stellata + (S. parawoolletti + S. woolletti) and receive high bootstrap support and posterior probability $(\mathrm{BP}=99, \mathrm{PP}$ =1.00). We hereafter called the clade $S$. woolletti group. 

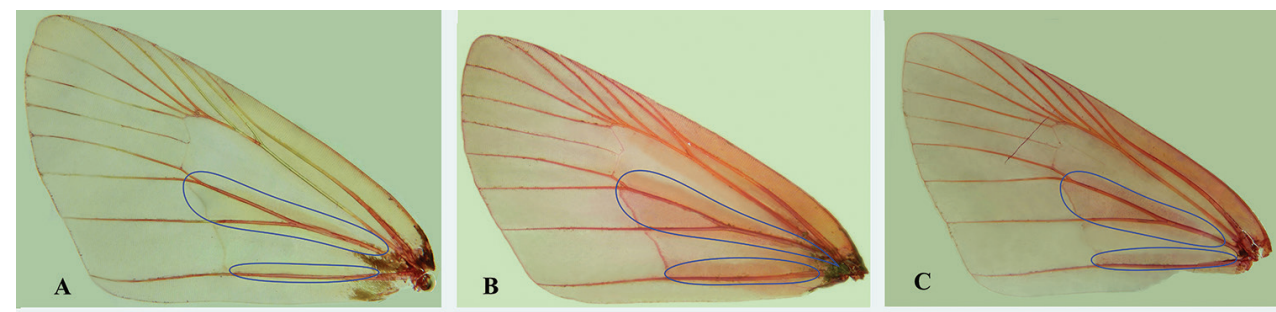

A. $S$. coniata Hering, 1918

B. S. evansi Devyatkin, 2004

C.S. lyso (Evans, 1939)

D. S. masutaroi Sugiyama, 1996

E. S. hainana (Gu \& Wang, 1997)
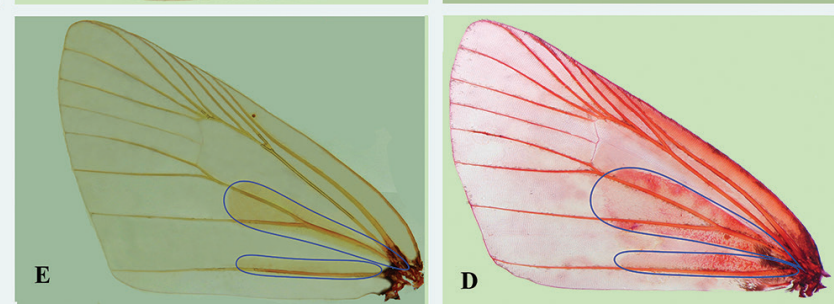

Figure 2. Male band of scent scales in the $S$. coniata group species.

Clade B is comprised by $S$. masutaroi and the representatives of $S$. coniata group (Devyatkin 2004): S. coniata, S. lyso and S. hainana, and the latter two are sister species with strong support $(\mathrm{BP}=93, \mathrm{PP}=1.00)$. The monophyly of $S$. coniata group including $S$. masutaroi is strongly supported $(\mathrm{BP}=100, \mathrm{PP}=1.00)$.

In all the analyses, $S$. cephaloides is sister to Clade $\mathrm{B}$, with moderate support $(\mathrm{BP}=$ 63, PP $=0.92$ ), whereas the relationships between $S$. isota and the other clades (Clade A, S. cephaloides and Clade B) remain unresolved.

\section{Discussion}

Although our phylogenetic analyses do not strongly support the monophyly of the genus Scobura, two strongly supported monophyletic groups within the genus are recognized: the $S$. coniata group and the $S$. woolletti group. The members of the coniata group share the following four morphological characters: 1) male band of scent scales on both sides of veins $\mathrm{CuA}_{1}$ and $\mathrm{CuA}_{2}$ and above $2 \mathrm{~A}$ on the forewing (Fig. 2); 2) juxta U-shaped with two spine bearing arms, flat at base; 3) tegumen without socius; and 4) uncus thin and long. S. masutaroi is nested within this group. In our present analyses, two individuals (He 300, 301) of masutaroi from Nibashan, Sichuan (close to Dujiangyan, Sichuan, the type locality of $S$. masutaroi) and an individual (He303) from Jialingjiang, Fengxian, Shaanxi (the type locality of $S$. mouchai) are clearly grouped together with strong support values $(\mathrm{BP}=100, \mathrm{PP}=1.00)$. Moreover, the pairwise $\mathrm{P} 2 \mathrm{~K}$ distances in COI between the species in the S. coniata group range from $3.3 \%$ to $6.1 \%$ with divergences between species averaging $4.5 \%$, while divergence between individuals of S. masutaroi from Sichuan and Shaanxi province was $0.2 \%$.

Based on the original description, distribution data, and the illustrations provided by Krajcik (2013), as well as our phylogenetic inferences, we conclude that $S$. mouchai 
is identical to $S$. masutaroi and should be considered a junior synonym. The male genitalia are illustrated herein, and the female genitalia are described for the first time. On the basis of morphological study (Devyatkin, 2004), two other species, S. phuongi and S. evani, which are not included in the present study, likely also belong to this group.

A well-support clade comprised by S. stellata, S. parawoolletti and S. woolletti was recovered in all analyses. These species share the following three characters: 1) hindwing with white spots on underside but not on upperside; 2) socius slender and pointed at tip; and 3) juxta funnel-like, thin and long basally. The generic name Mimambrix Riley, 1923 was proposed with Mimambrix woolletti as the type species, but later synonymized by Evans (1949). We follow Evans' treatment and consider this clade as a species group within the genus Scobura. Based on morphological characters, the group also includes S. tytleri (Evans, 1914).

\section{Taxonomic account}

The key given by Fan et al. (2010) is modified to include $S$. masutaroi. The couplets leading to $S$. masuataroi only are included here. Couplets beyond 11 in the original increase their number by one.

Forewing upper side without spots in spaces $\mathrm{M}_{3}$ or $\mathrm{M}_{1}$ and $\mathrm{M}_{2} \ldots \ldots \ldots \ldots \ldots \ldots . . .4$

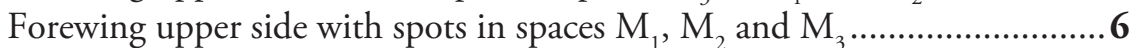

$4 \quad$ Forewing upper side without spots in spaces $M_{1}$ and $M_{3}$ hindwing under side: basal half yellow, distally ferruginous, with five small spots ........S. cephaloides Forewing upper side without spot in space $M$ 5 Hindwing under side with a conspicuous rectangular white spot in space $\mathrm{CuA}_{2}$ S. cephala Hindwing under side without a conspicuous rectangular white spot in space $\mathrm{CuA}$ S. isota Hindwing upper side without spot in space $\mathrm{CuA}_{1}$, under side with small white spots in spaces $S_{c}+R_{1}, M_{1-2}, M_{3}$ and cell S. eximia Hindwing upper side with the spot in space $\mathrm{CuA}$

Forewing cell spots separated, if conjoined, the lower spot much larger ......9

$8 \quad$ Hindwing upper side hyaline spots white. S.evansi Hindwing upper side hyaline spots yellow S.masutaroi Forewing upper side the spot in space $\mathrm{CuA}_{2}$ triangular, and with a linear stigma crossing the spots in spaces $\mathrm{CuA}_{1}$ and $\mathrm{CuA}_{2}$. Forewing upper side the spot in space $\mathrm{CuA}_{2}$ not as above

10 Forewing upper side the spot in space $\mathrm{CuA}_{1}$ narrow, hindwing upper side without spot in space. 
11 Hindwing upper side spot in space $\mathrm{M}_{3}$ tiny dot, forewing upper side cell spots cell spots conjoined

S. hainana

- $\quad$ Hindwing upper side spot in space $M_{3}$ significant, forewing upper side cell spots cell spots separated

S. phuongi

\section{Scobura masutaroi Sugiyama, 1996}

Fig. 3

Scobura masutaroi Sugiyama, 1996: 9 (Type locality: Dujiangyan, Sichuan, China) Scobura mouchai Krajcik, 2013: 2, syn. n. (Type locality: Fengxian, Shaanxi, China)

Material examined. 1 $\hat{0}, 1$, , Nibashan, Rongjing, Sichuan, 26.VII.2009, Min Wang; $1 \hat{O}$, Jialingjiang, Fengxian, Shaanxi, 15.VII.2010, Min Wang.

Diagnosis. Forewing length $17-18 \mathrm{~mm}$. This species is different from other species of $S$. coniata group in the appearance of the wing upper side: forewing with yellow streak in subcosta space basally, a big cell spots solid across cell, the spot in space $\mathrm{CuA}_{2}$ yellow; hindwing with spots in spaces $\mathrm{CuA}_{1}$ and $\mathrm{M}_{1}-\mathrm{M}_{2}$ yellow. Wing under side: forewing costal and submarginal spots yellow; hindwing all veins and submarginal spots from spaces $\mathrm{Sc}+\mathrm{R}_{1}$ to $\mathrm{CuA}_{2}$ yellow; and all yellow submarginal spots conjoined both forewing and hindwing.

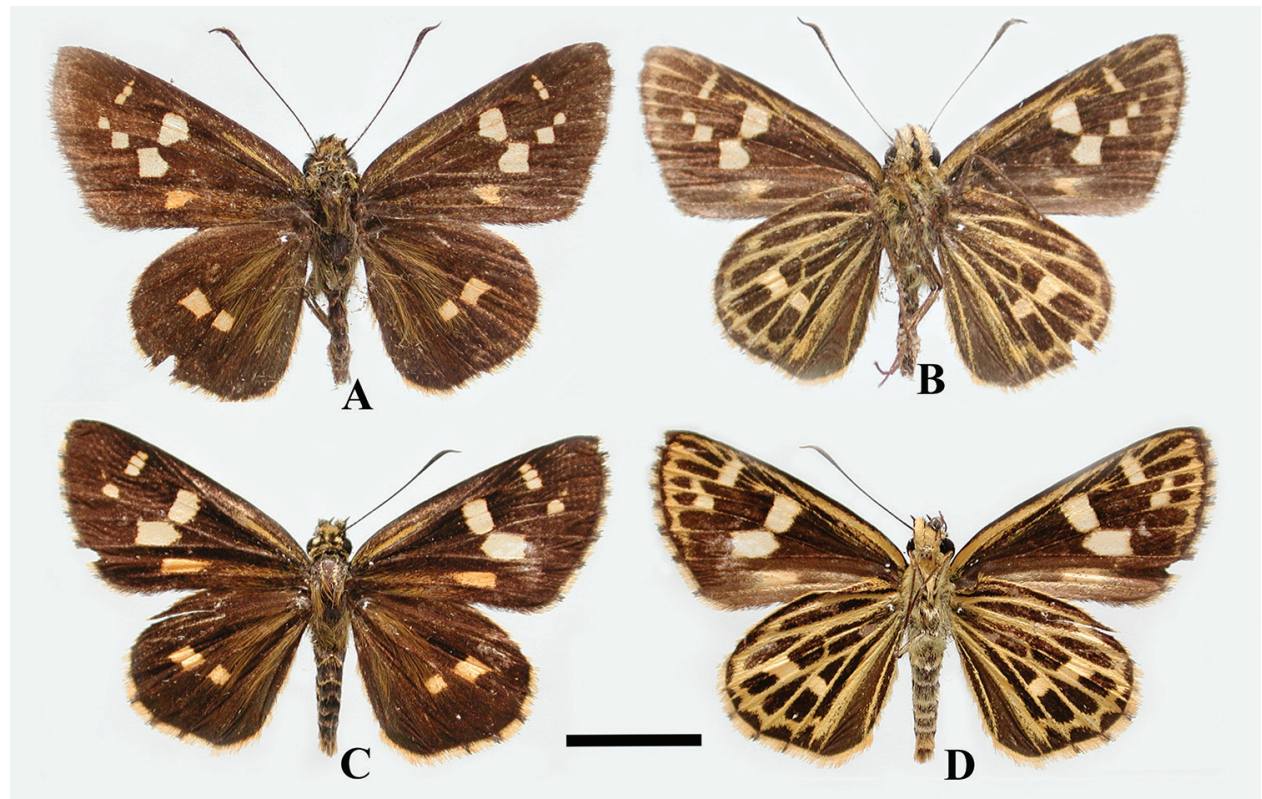

Figure 3. Scobura masutaroi Sugiyama, 1996 (Sichuan): A, B male C, D female; scale bar $10 \mathrm{~mm}$. 


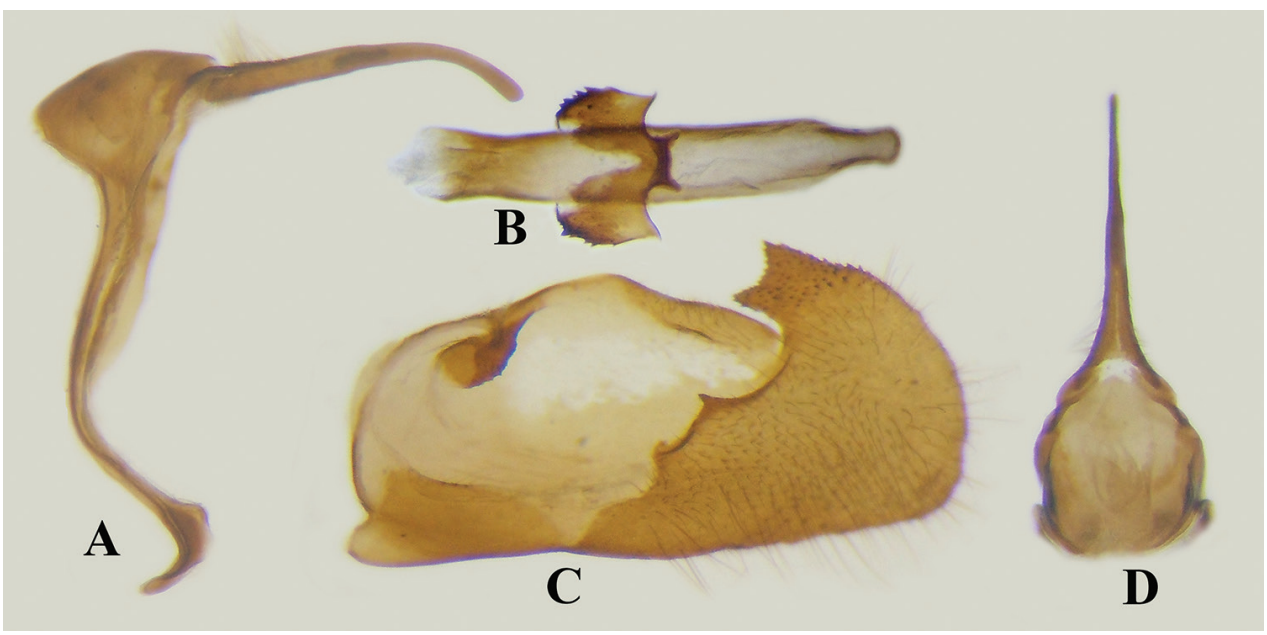

Figure 4. Male genitalia of Scobura masutaroi Sugiyama, 1996. (Sichuan). A Genitalia ring, lateral view; B aedeagus and juxta. C valva, inner view; D tegument, dorsal view.

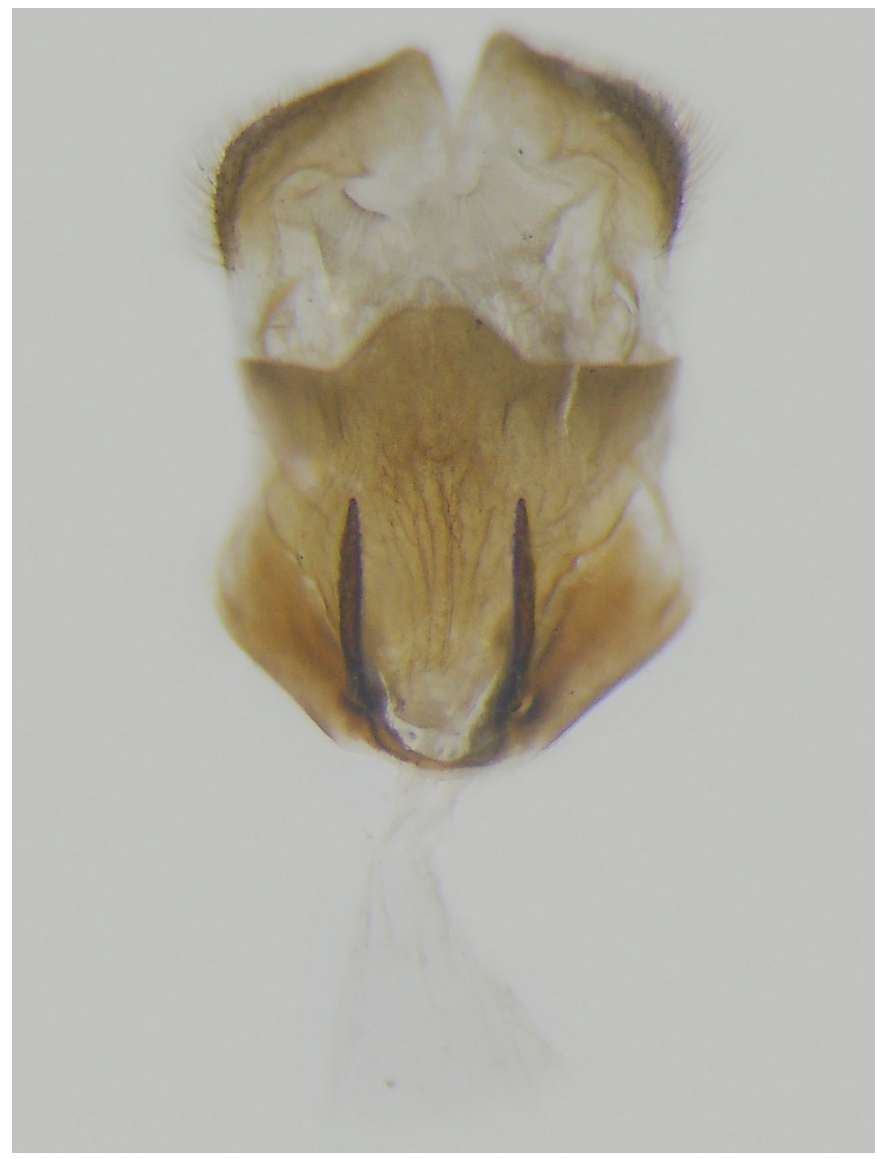

Figure 5. Female genitalia of Scobura masutaroi Sugiyama, 1996 (Sichuan) 
Description. Male genitalia (Fig. 4): Tegumen without socius, weakly rounded from lateral view; uncus slender and much longer than tegumen; valva with transtilla rounded and sclerotized with small spines, ventro-distal process irregularly shaped with outer edge rounded, inner edge uneven, and distal part rectangular with densely small spines; saccus short and broad; gnathos absent; juxta U-shaped with two arms with densely spines.

Female genitalia (Fig. 5): Papillae anales rectangular, covered with setae; anterior lamella U-shaped with sclerotization; posterior lamella triangular with upper margin arched; ductus bursae membranous and short; copulatrix bursa elongate, membranous.

Distribution. China (Sichuan, Shaanxi).

\section{Acknowledgements}

We are grateful to Drs Liu-Sheng Chen (Shihezi University, Xinjiang, China), Houshuai Wang and Hai-ming Xu (SCAU) for collecting the specimens. Materials of some species were provided by the Kyushu University museum, Dr Osamu Yata and Mr Hiroaki Onodera. The work is supported by the Natural Science Foundation of China (NSFC- 31172136 and -31471984).

\section{References}

Devyatkin AL (2004) Taxonomic studies on Oriental Hesperiidae, 1. A revision of the Scobura coniata Hering, 1918-group. Atalanta 35(1/2): 57-66.

Evans WH (1949) A catalogue of the Hesperiidae from Europe, Asia \& Australia in the British Museum (Natural History). The British Museum, London, England, United Kingdom, 502 pp. https://doi.org/10.5962/bhl.title.105941

Fan XL, Chiba H, Wang M (2010) The genus Scobura Elwes \& Edwards, 1897 from China, with descriptions of two new species (Lepidoptera: Hesperiidae). Zootaxa 2490: 1-15.

Folmer O, Black M, Hoeh W, Lutz R, Vrijenhoek R (1994) DNA primers for amplification of mitochondrial cytochrome c oxidase subunit I from diverse metazoan invertebrates. Molecular marine biology and biotechnology 3: 294-299.

Gu MB, Chen PZ (1997) Butterflies in Hainan Island. China Forestry Publishing House. Beijing, China, 337 pp.

Krajcik M (2013) Description new Scobura Elwes and Edwards from Shaanxi Province and notes on the genus Ampittia Moore in China (Lepidoptera, Hesperioidea, hesperiinae). ANMMA 10(57): 1-3.

Miller MA, Pfeiffer W, Schwartz T (2010) Creating the CIPRES Science Gateway for Inference of Large Phylogenetic Trees. In: SC10 Workshop on Gateway Computing Environments (GCE10). https://doi.org/10.1109/GCE.2010.5676129 
Monteiro A, Pierce NE (2001) Phylogeny of Bicyclus (Lepidoptera: Nymphalidae) Inferred from COI, COII, and EF-1 $\alpha$ Gene Sequences. Molecular Phylogentic Evolution 18(2): 264-281. https://doi.org/10.1006/mpev.2000.0872

Rambaut A, Suchard MA, Xie D, Drummond AJ (2014) Tracer v1.6. http://beast.bio.ed.ac. uk/Tracer

Riley ND (1923) New Rhopalocera from Borneo. Entomologist 56: 35-38.

Ronquist F, Teslenko M, van der Mark P, Ayres DL, Darling A, Höhna S, Larget B, Liu L, Suchard MA, Huelsenbeck JP (2012) MrBayes 3.2: Efficient Bayesian Phylogenetic Inference and Model Choice Across a Large Model Space. Systematic Biology 61: 539-542. https://doi.org/10.1093/sysbio/sys029

Stamatakis A (2014) RAxML Version 8: A tool for Phylogenetic Analysis and Post-Analysis of Large Phylogenies. Bioinformatics. https://doi.org/10.1093/bioinformatics/btu033

Sugiyama H (1996) New Butterflies from Western China (IV). Pallarge 5: 1-11.

Tamura K, Stecher G, Peterson D, Filipski A, Kumar S (2013) MEGA6: Molecular Evolutionary Genetics Analysis version 6.0. Molecular Biology and Evolution 30(12): 2725-2729. https:// doi.org/10.1093/molbev/mst197

Thompson JD, Gibson TJ, Plewniak F, Jeanmougin F, Higgins DG (1997) The Clustal X windows interface: flexible strategies for multiple sequence alignment aided by quality analysis tools. Nucleic Acids Research 24: 4876-4882. https://doi.org/10.1093/nar/25.24.4876

Wang HS, Xiong W, Wang M (2011) Two new species of the genus Longipenis (Lepidoptera: Lecithoceridae) from China. Florida Entomology 93: 352-356. https://doi. org/10.1653/024.093.0305 